UNIVERSITY OF GOTHENBURG

SCHOOL OF BUSINESS, ECONOMICS AND LAW

WORKING PAPERS IN ECONOMICS

No 492

Do Microloan Officers Want to Lend to the Less Advantaged? Evidence from a Choice Experiment.

Moïse Sagamba

Oleg Shchetinin

Nurmukhammad Yusupov

February 2011

ISSN 1403-2473 (print)

ISSN 1403-2465 (online)

Department of Economics

School of Business, Economics and Law at University of Gothenburg

Vasagatan 1, PO Box 640, SE 40530 Göteborg, Sweden

+46317860000, +46317861326 (fax)

www.handels.gu.se info@handels.gu.se 


\title{
Do Microloan Officers Want to Lend to the Less Advantaged? Evidence from a Choice Experiment*
}

\author{
Moïse Sagamba ${ }^{\dagger} \quad$ Oleg Shchetinin Nurmukhammad Yusupov $^{\ddagger}$
}

February 25, 2011

\begin{abstract}
The mission of microfinance is generally perceived as compensation for the failure of the mainstream financial institutions to deliver access to finance to the poor. Microloan officers have significant influence on microloans allocation as they contact loan applicants and process information inside microfinance institutions (MFIs). We conduct a choice experiment with microloan officers in Burundi to determine which clients are preferred for microloan allocation and whether the less advantaged are indeed targeted. The results suggest that the allocation of microloans is slightly in favor of the less advantaged, whereas the main determinant is the quality of the applicants' business projects. Somewhat surprisingly, we find only small differences in the determinants of the targeted groups between non-profit and profit-seeking MFIs.
\end{abstract}

Keywords: microfinance, choice experiment, microloan officers, non-profit organizations.

JEL Classification Numbers: C83, C93, G21, L31, O55.

${ }^{*}$ We are grateful to the directors and management of all MFIs who kindly agreed to participate in our study and allowed us to involve their personnel. We are also grateful to all loan officers participating in the study. Financial support from the Jan Wallander and Tom Hedelius Foundation and "Bureau MAXX" in Bujumbura is greatly acknowledged. Bébelyne Kanyange and Sabrina Bigirimana provided excellent research assistance. We also thank Peter Martinsson, Fredrik Carlsson, Olof Johansson-Stenmann, Oysten Strøm, and the participants of the World Meeting of the Economic Science Association in Copenhagen, the Third International Workshop on Microfinance Governance and Management in Groningen, and The 2010 Northeast Universities Development Consortium Conference in Cambridge, MA, for useful comments and discussions.

†Université Lumière de Bujumbura and Université de Bretagne Occidentale. <sagmoi@yahoo.fr>

${ }^{\ddagger}$ Corresponding author. Department of Economics, School of Business, Economics and Law, University of Gothenburg. <oleg.shchetinin@economics.gu.se>

${ }^{\S}$ Chaire Banque Populaire, Audencia Nantes School of Management. <nyusupov@audencia.com> 


\section{Introduction}

Where the mainstream financial institutions have failed to deliver access to capital, microfinance institutions (MFIs) have successfully been filling the institutional void. The mainstream financial institutions often find it costly or impossible to enforce loan contracts with the poor due to the softness of information ${ }^{1}$ and small size of transactions leading to high operational costs. Yet, the MFIs have managed to maintain surprisingly high repayment rates. Their success is largely attributed to innovative financial contracts $^{2}$. However, despite burgeoning research on the implications of these contracts and lending schemes, the role of microloan officers in the success of MFIs is largely overlooked. Indeed, the officers contact loan applicants to extract information and make recommendations on granting a loan. Additionally, they extensively monitor the borrowers once the microloan is issued.

The softness of information about borrowers implies that its quality heavily depends on how it is processed by a microloan officer. Specifically, individual preferences of the officers, as well as incentives provided to them, should significantly affect microloans allocation. Therefore, while the mission of many MFIs implies poverty alleviation and social inclusion through targeting the less advantaged, whether they indeed fulfill this mission $^{3}$ is to a large extent determined by preferences and activities of microloan officers.

\footnotetext{
${ }^{1}$ See Petersen (2004) for a conceptual discussion of soft vs. hard information in finance

${ }^{2}$ Microcredit contracts usually leverage on joint-liability, dynamic incentives, and relationship building to offer unsecured loans. For general surveys, see Morduch (1999) and Karlan and Morduch (2009). For microloan contracts, see Ghatak and Guinnane (1999), Hermes and Lensink (2007), Fischer and Ghatak (2010), and Galariotis et al. (2011). For a broader introduction to the economic issues within the microfinance industry see Armendáriz and Morduch (2010).

${ }^{3}$ There is evidence that many non-profit MFIs have started serving the less poor to improve their financial results (Cull et al. (2009)) driven by the pressure for financial viability. This trend toward commercialization raises a concern, often referred to as "mission drift" (Mersland and Strøm (2010)). Whether and how much MFIs help the poor by offering microloans remains a subject of intense debate (Banerjee et al. (2009)).
} 
We run a choice experiment to reveal microloan officers' preferences over loan allocation. The experiment was run in Burundi and involved about half of all microloan officers in the country. We incorporate three groups of characteristics of the potential borrowers and their projects: first, age, gender, and poverty level, which are generally considered to be the key measures of social impact of microfinance (Cull et al. (2009)). Second, project characteristics, such as probability of timely repayment, difficulty of monitoring, and loan size. Third, other relevant characteristics, i.e., family composition, previous occupation of the applicant, and accommodation size. We control for MFI type (profit-seeking and non-profit), incentives provision, and personal characteristics of microloan officers.

Our choice experiment methodology is based on stated preferences ${ }^{4}$. A better alternative would be to build on revealed preferences by analyzing data on actual applications for microloans. However, this is often very costly and sometimes even impossible in impoverished developing countries, since record keeping is carried out primitively with pen and paper by individual microloan officers and the records are not stored systematically ${ }^{5}$. Thus, a plausible alternative is to use a controlled field experiment, ${ }^{6}$ which enables us to overcome the above-mentioned problems with field data. Importantly, the subjects in our experiment are real microloan officers carrying out a task closely resembling their on-job duties.

Our findings suggest that there is little difference between preferences of microloan officers employed by non-profit and profit-seeking MFIs in Burundi. For instance, officers

\footnotetext{
${ }^{4}$ The use of choice experiments is new in development economics, yet the method has proved to be useful in cases when it is hard to observe or evaluate revealed preferences (see List et al. (2006)). Choice experiments have been used for the evaluation of non-market goods, such as quality of the environment or health (see, e.g., Carlsson and Martinsson (2001)). Ibanez and Carlsson (2010) use a choice experiment to study the effectiveness of policies targeting coca cultivation.

${ }^{5}$ During the field stage of our project, some MFIs in Burundi had just started using or were considering starting to use computerized databases to monitor loan repayments. No electronic databases were used for appraisal of loan applications. It is reasonable to expect similar circumstances in other poor countries

${ }^{6}$ See Levitt and List (2009) for the taxonomy of experiments.
} 
from non-profit MFIs are only slightly more sensitive to applicant gender (women are slightly more preferred for granting a microloan). The impact of poverty does not differ significantly. Moreover, the poorest applicants have lower chances of being granted a microloan irrespective of MFI type. The more mature applicants under the age of 40 are more likely to get a loan, whereas those older than 40 have lower chances. This tendency is stronger for non-profit MFIs. Overall, the results suggest that loan officers generally treat social characteristics of applicants similarly regardless of type of MFI. We find that the characteristics of the project for which a loan is requested are the most important determinants of granting a loan in both types of MFIs. The most significant difference between the two types of MFIs is found in the impact of monitoring possibilities: the more difficult is to monitor the loan utilization, the less benefits a microloan officer derives from granting a loan. This correlation appears to be stronger for the officers from for-profit MFIs. Additionally, we find that monetary incentives for loan officers are rarely used in Burundian MFIs, yet when they are used, they seem to influence loan allocation in the intended way.

This paper contributes to the important new strand of microfinance research that focuses on the role of microloan officers in the delivery of microfinance services. To our knowledge, this literature is very thin. Labie et al. (2010) provide empirical evidence that microloan officers' preferences can influence the allocation of microloans based on a study in Uganda. They show that microloan officers are biased against disabled borrowers (in fact, even more so than other MFI employees). Their analysis suggests that provision of incentives to the credit officers may alleviate this problem, but can be too costly. McKim and Hughart (2005) document that incentives for microloan officers are usually based on the loan repayment rate and/or an indication of outreach, such as the share of loans allocated to the poorest in the loan portfolio. Aubert et al. (2009) conclude that pro-poor 
MFIs face a trade-off in designing incentives: to guarantee financial viability, incentives must be based on repayment rate, which can backfire on the social mission of these MFIs. Their study stresses that the perceived mission drift can emerge due to organizational problems inside the MFI, but it can be less persistent if microloan officers are intrinsically $\operatorname{motivated}^{7}$ to lend to the poorest applicants.

Our paper provides field experiment evidence on the determinants of microloan officers preferences regarding loan allocation. Specifically, we find that financial viability considerations dominate pro-social mission fulfillment, and different types of MFIs converge in the patterns of loan allocation in the environment where profit-seeking and non-profit MFIs coexist. Our results support the view that provision of incentives for microloan officers alters their preferences and, consequently, influences microloan allocation.

The paper proceeds as follows: in the next section we summarize the theory of choice experiments. Section 3 describes in detail our experimental design. The empirical results are presented in Section 4 and implications are discussed in Section 5.

\section{Theoretical Grounds for Choice Experiment}

\subsection{Utility of Microloan Officer}

Suppose that a microloan officer is considering granting a microloan to a particular applicant with a particular project ${ }^{8}$. Assume that the officer gets some benefit from attributing the loan and that his expected subjective utility increases by $u$. The magnitude of $u$ is

\footnotetext{
${ }^{7}$ As a rule, intrinsic motivations can reduce agency costs (Besley and Ghatak (2005), Francois and Vlassopoulos (2008)).

${ }^{8}$ As we mentioned in the Introduction, in reality the officer only gives a recommendation, and the final decision on granting a loan is taken by the board of MFI or other approving body. However, the decision is largely based on the officer's recommendation.
} 
mainly determined by three groups of factors:

- characteristics of the project;

- characteristics of the applicant;

- personality of the microloan officer and organizational structure of the MFI.

Consider in detail these factors to support our claim.

Project characteristics can influence the microloan officer's expected benefits from granting a loan to the project. For example, if loan repayment delays are very likely, then the (expected) benefits can be low as the officer will need to spend more time and effort, e.g., visiting the entrepreneur and finding ways to ensure loan repayment, and renegotiating the conditions of the loan. The officer can also be paid a lower wage, or may feel guilty to his or her peers. Difficulty of monitoring is another project characteristic that can increase the future cost of fulfilling on-the-job duties and, as a consequence, decrease the officer's expected benefits from granting a loan.

A microloan officer's utility from granting a loan can depend on personal (social) characteristics of the applicant. For example, a microloan officer may derive higher utility from allocating loans to women, younger people, or the poorer. Such an increase in subjective benefit can be driven by fulfillment of the MFI's mission or by the microloan officer's personal predisposition.

Finally, benefits, derived by different officer from granting a loan to an applicant may depend on officer characteristics and the MFI for which the officer works. For example, officers may differ in pro-social orientation and thus differ in sensitivity to particular groups of applicants, such as the poorest or women. Also, an officer's expected benefit can be influenced by the incentive structure and objectives of his/her MFI (non-profit or profit-seeking). 
The assumption on the determinants of the expected benefits for a microloan officer can naturally be formalized as follows. Let the microloan officer be characterized by vector $\beta=\left(\beta_{1}, \ldots, \beta_{K}\right)^{T}$ and the characteristics of the project/applicant be summarized by vector $x=\left(x_{1}, x_{2}, \ldots x_{K}\right)^{T}$. The value of $\beta_{k}$ is the officer's marginal valuation of the $k$-th characteristic of the project/applicant.

Benefits, derived by the microloan officer by granting a microloan to an applicant $i$, characterized by $x_{i}=\left(x_{i 1}, x_{i 2}, \ldots x_{i K}\right)$, are given by

$$
u\left(\beta, x_{i}\right)=\sum_{k=1}^{K} \beta_{k} x_{i k}+\varepsilon_{i}
$$

Let us assume that the microloan officer is to choose only one applicant from a set of two. Let $S=\left\{t, t^{\prime}\right\}$ be the set of applicants. The probability that an applicant $t$ is chosen for loan attribution is given by

$$
P(t \mid S, \beta)=P\left(\beta^{T} x_{t}+\varepsilon_{t}>\beta^{T} x_{t^{\prime}}+\varepsilon_{t^{\prime}}\right)
$$

To capture heterogeneity of microloan officers, we will further suppose that $\beta$ can be decomposed into a population-common component $\bar{\beta}$ and an officer-specific component $\widetilde{\beta}:$

$$
\beta=\bar{\beta}+\widetilde{\beta}
$$

For instance, $\widetilde{\beta}$ can be a component specific to officers working in profit-seeking MFIs. Alternatively, it can represent a component specific to microloan officers working under a particular incentive scheme. 


\subsection{Brief Theory of Choice Experiment Design}

Consider a general choice experiment setting.

The set of all possible alternatives is called the candidate set. Assume that there are $N$ choice sets $S_{1}, S_{2}, \ldots, S_{N}$, each of them being a subset of the candidate set and consisting of $J_{n}$ alternatives. An alternative $t$ is characterized by $K$-dimensional vector of attributes $x_{t}=\left(x_{t 1}, \ldots, x_{t K}\right)$. Decision maker $j$, characterized by vector $\beta_{j}=\left(\beta_{j 1}, \ldots, \beta_{j K}\right)$, derives utility $u\left(\beta_{j}, x_{t}\right)=\sum_{k=1}^{K} \beta_{j k} x_{t k}+\varepsilon_{j t}$ from choosing alternative $t$.

Under the assumption that $\varepsilon_{j \tau}\left(\tau=t, t^{\prime}\right)$ are independently and identically distributed with a Gumbel distribution, the selection probability for alternative $t$ given choice set $S$ and characteristics of the choice maker $\beta_{j}$ is

$$
P\left(t \mid S, \beta_{j}\right)=\frac{\exp \left(\beta_{j}^{\prime} x_{t}\right)}{\exp \left(\sum_{\tau \in S} \beta_{j}^{\prime} x_{\tau}\right)}
$$

The model leading to these selection probabilities is called the conditional logit model. McFadden (1974) offers a detailed analysis, showing, for instance, that the maximum likelihood estimator for $\beta$ in the conditional logit model has covariance matrix

$$
\Omega=\left(Z^{\prime} P Z\right)^{-1}=\left(\sum_{n=1}^{N} \sum_{j=1}^{J_{n}} z_{j n}^{\prime} P_{j n} z_{j n}\right)^{-1}
$$

where $z_{j n}=x_{j n}-\sum_{i=1}^{J_{n}} x_{i n} P_{i n}$ and $P_{j n}$ is the probability of choosing an alternative $j$ from choice set $S_{n}$. The norm of the covariance matrix is called D-error

$$
D \text {-error }=[\operatorname{det}(\Omega)]^{1 / K}
$$


Importantly, D-error depends on the experimental design, i.e., the composition of the choice sets $S_{1}, \ldots, S_{N}$.

The assumption of a Gumbel distribution of the error terms $\varepsilon$ can be relaxed. The model can also be estimated with alternative specifications: robust estimation of the covariance matrix, cluster error structure, or by using a bootstrap estimator. These alternative specifications will be used for robustness check of the empirical results in our study.

Although the D-error determined by (3) represents the norm of the covariance matrix of the estimator of $\beta$ only under the assumption that errors are Gumbel-distributed, it is commonly used as a measure of statistical efficiency of the experimental design in general case. Alternative efficiency measures yield similar results (in terms of expected efficiency of designs) if the number of alternatives included in the design is large enough (Kessels et al. (2006)).

The optimal design of the choice experiment, i.e., the composition of the choice sets $S_{1}, \ldots, S_{N}$, is usually obtained by minimizing the D-error ${ }^{9}$. We adopt this criterion.

\section{Design of the Experiment with Microloan Officers}

In this section we describe how the candidate set of applicants' profiles is constructed in our choice experiment. We then describe the procedure for obtaining the set of profiles presented to the respondents.

\footnotetext{
${ }^{9}$ More precisely, the design obtained by minimizing D-error is called D-efficient design. Alternative criteria could be used and lead to different optimal designs. As mentioned, the expected efficiency of designs, which are optimal according to different criteria, are very close, given that a large enough number of alternatives is included in the design.
} 


\subsection{The Candidate Set}

In our experiment, the profiles of the applicants consist of nine attributes. As stated in subsection 2.1, these attributes can be divided into three broad categories: first, personal characteristics of the applicant - age, gender, and poverty level. These are generally considered to be important aspects of microfinance pro-social mission fulfillment. Second, project-related attributes - project quality, characterized by the probability of timely loan repayment for a similar type of project, loan size, and difficulty of monitoring. These characteristics are essential for financial viability of MFIs. Third, other applicant characteristics, e.g., family size (number of persons in the household), accommodation size, and applicant's previous occupation, as they, among other factors, may influence the loan decision.

The list of applicant/project attributes used in the choice experiment and their values are shown in Table 1.

On top of this, we control for type of MFI, incentive structure, and personal characteristics of microloan officers in the analysis of the choice experiment results.

Although the number of attributes is quite large, which could complicate the examination of the alternatives for the respondents, these exact attributes are analyzed by the microloan officers in their daily work. This was confirmed during the preparation stage of our study in discussions with the management of the participating MFIs. Therefore, we believe that the respondents in our experiment were able to handle all the information presented in the profile descriptions within a reasonably short time. Additionally, we control for representation effects, which may lead to disregard of some information presented to the respondent ${ }^{10}$.

\footnotetext{
${ }^{10}$ See discussion of experimental design representations at the end of subsection 3.2 .
} 
Table 1: The list of attributes and its values.

\begin{tabular}{|c|c|c|}
\hline Attribute & \# of values & List of values \\
\hline Age & 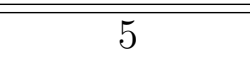 & $18 ; 22 ; 27 ; 34 ; 44$ years \\
\hline Gender & 2 & Female; Male \\
\hline Poverty level & 3 & $\begin{array}{l}\text { Poor; Very poor; Extremely poor, corresponding } \\
\text { to monthly income of } 11000 ; 15000 ; 30000 \mathrm{FBu} \text {, } \\
\text { equivalent to } 9 ; 12 ; 24 \text { USD }\end{array}$ \\
\hline $\begin{array}{l}\text { Prob. of timely } \\
\text { repayment }\end{array}$ & 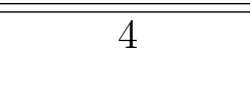 & $\begin{array}{l}\text { Graphical scale, ranging from "half of the cases" } \\
\text { to almost sure }\end{array}$ \\
\hline $\begin{array}{l}\text { The size of the } \\
\text { loan }\end{array}$ & 3 & $\begin{array}{l}\text { Small; Medium; Large, corresponding to } 250000 ; \\
600000 ; 1000000 \mathrm{FBu} \text {, equivalent to } 200 ; 484 ; 806 \\
\text { USD }\end{array}$ \\
\hline $\begin{array}{l}\text { Difficulty of mon- } \\
\text { itoring }\end{array}$ & 3 & Easy; With some difficulties; Difficult \\
\hline $\begin{array}{l}\text { Number of per- } \\
\text { sons in the house- } \\
\text { hold }\end{array}$ & 4 & $\begin{array}{l}\text { Living alone; Living in couple(2); } 2+2 \text { children; } \\
2+2 \text { ch.+older }\end{array}$ \\
\hline Accommod. size & 4 & Accommodation of $1 ; 2 ; 3 ;$ more than 3 pieces. \\
\hline $\begin{array}{l}\text { Previous occupa- } \\
\text { tion }\end{array}$ & 3 & $\begin{array}{l}\text { Student; Employed at another enterprize; Unem- } \\
\text { ployed }\end{array}$ \\
\hline
\end{tabular}

Some profiles with certain combinations of attributes seem to be unrealistic. To avoid confusion among the respondents, we excluded such profiles from the experiment design. Precisely, we have excluded profiles with the following combinations of the attribute values:

- Age: 34 or 44 years AND Previous occupation: student;

- Accommodation size: 3 pieces or more than 3 pieces AND Number of persons in the household: Living alone;

- Accommodation size: 1 piece AND Number of persons in the household: Married with two children and the elderly, living together;

- Age: 18 years AND Number of persons in the household: Married with two children, 
living together or Married with two children and the elderly, living together;

- Age: 22 years AND Number of persons in the household: Married with two children and the elderly, living together.

The set of all non-excluded 9-attribute profiles form the candidate set. All in all, it consists of 27216 profiles.

\subsection{The Procedure for Experimental Design Construction}

We use a two-stage procedure to construct the experimental design. At the first stage, an optimal design consisting of 120 profiles is obtained. They forme 60 choice sets consisting of 2 profiles each ${ }^{11}$. At the second stage, we construct four different representations of the optimal design to control for presentation effects. The details are explained below.

The first stage is a modified version of the design improvement algorithm proposed by Zwerina et al. (1996). In the original version, the 60-pair, or 120-profile, design is randomly selected from the candidate set and is used as the starting point of the algorithm. We select the starting point in a different way, as explained below, yet followed the original version of the algorithm in all subsequent steps.

Once selected, the starting point is cyclically improved. First, all the profiles from the candidate set are tried for the first profile in the 120-profile design. The one minimizing D-error ${ }^{12}$ replaces the first profile in the 120 -profile design. After going through all the 120 profiles, the D-error of the experimental design is computed and compared with the

\footnotetext{
${ }^{11}$ The profiles in the obtained design can be ordered and then each choice set consists of one oddand one even-numbered profile. We will use this simple remark to explain how we obtain different representations of each choice set.

${ }^{12} \mathrm{We}$ had no preliminary information regarding the coefficients of the utility function of the respondents, so to compute D-errors we used an "unrestricted- $\beta$ " assumption, i.e., we took $\beta=0$, as it is usually done.
} 
D-error of the starting point. The algorithm restarts until the improvement after the cycle of 120 iterations reaches a threshold limit (we used a 0.95 rule, i.e., the algorithm stops if the D-error after 120 iterations is not smaller than 0.95 multiplied by the previous D-error).

To motivate the departure from using randomly selected design as a starting point of the improvement algorithm, note that given the large number of attributes and, consequently, the large size of the candidate set (27216 profiles), each cycle of improvements takes a long time. Thus, by choosing the starting design with a small enough D-error, the number of restarts of the algorithm can be sufficiently reduced and the implementation of the algorithm becomes much less time-consuming ${ }^{13}$.

We construct the starting point in the following way. We separate the set of attributes into two subsets: one consisting of 4 attributes with $3,4,4$, and 5 values and one consisting of 5 attributes with 2,3,3,3, and 4 alternatives ${ }^{14}$. For each of these subsets, the computations to construct an optimal 120-profile design go fast. Then the two sets of sub-profiles are merged and the resulting profile is used as a starting point for the design improvement algorithm described above.

We will now move on to the second stage, at which four representations of the optimal design are constructed.

First we construct two representations to control for "side-presentation effect". In the questionnaire, one profile from each choice set is presented on the left and another one is

\footnotetext{
${ }^{13}$ The choice of the starting point is a purely practical matter. If one has enough computer capacity, the choice of starting point is not an issue. However, if one wants to be able to change experimental design in the course of field experiment, one can possess only a limited capacity for the experimental design improvement - for example, only one notebook can be available. Of course, changing an experimental design does not mean loosing the data collected with the previous design - all the data can be pooled together for analysis.

${ }^{14}$ This allowed us to construct optimal design consisting of 120 alternatives for each subset of parameters.
} 
presented on the right. Experimental studies suggest that when it is difficult to make a choice, most respondents tend to choose the left-hand alternative. To control for possible "side-presentation effect", two representations of the optimal design are constructed. In one representation, the odd-numbered alternatives of the optimal design are presented on the left and the even-numbered alternatives are presented on the right. In another representation, the alternatives in each choice set are swapped.

Second, we construct two versions of each of the two representations to control for attribute order effect. Given that the list of alternatives is rather long, the respondents may concentrate only on part of it, e.g., on the alternatives at the top of the list or those toward bottom. The alternatives in the middle of the list may have a weaker influence on the decisions merely because of their position. To control for possible attribute order effect, for each choice set representation we construct two attribute orderings.

In the end, we are left with 240 pairs of profiles (choice sets), obtained from a 60-pair optimal design by using 4 different representations for each pair. ${ }^{15}$ During the study, each respondent was given a set of 20 pairs of profiles such that all the choice sets presented to one respondent had the same ordering of attributes.

\footnotetext{
${ }^{15}$ The exact composition of the optimal design and the questionnaires used in the field can be obtained from the corresponding author on request.
} 


\section{Empirical Results}

\subsection{Sample description}

We surveyed 112 microloan officers ${ }^{16}$ at 21 MFIs $^{17}$ in 11 provinces in Burundi. Thus, our sample covers more than half of all microloan officers in Burundi. Our sample is representative of both non-profit and profit-seeking MFIs. It contains 84 microloan officers from 14 non-profit MFIs and 28 officers from 7 profit-seeking MFIs ${ }^{18}$.

In the choice experiment, each respondent was given 20 choice sets. We collected data on 1995 choice sets (out of 2240 possible), of which 1522 are from microloan officers employed in non-profit MFIs and 473 from officers employed in profit-seeking MFIs.

\subsection{Econometric Specification}

We use an alternative-specific conditional logit model. ${ }^{19}$ Following (1) and (2), the utility of a loan officer $j$ from giving a microloan to an applicant/project characterized by vector $x_{i}=\left(x_{i 1}, \ldots, x_{i 9}\right)$ with all $x_{i k}$ being categorical attributes is given by

$$
u=\sum_{k=1}^{9} \sum_{c=2}^{C_{k}} \beta_{k c} I_{x_{i k}=c}+\sum_{k=1}^{9} \sum_{c=2}^{C_{k}} \tilde{\beta}_{k c} I_{x_{i k}=c}+\varepsilon_{j i}
$$

where $k$ is an attribute index, $C_{k}$ is the number of categories for attribute $k, x_{i k}$ are categorical variables described in Table 1, $c$ is a category index, and $\varepsilon_{j i}$ are error terms that can be specific to loan officers. The category $c=1$ is used as a baseline

\footnotetext{
${ }^{16}$ Our sample consists mainly of microloan officers. There are also a small number of administrative councils members involved in the analysis of the applications for microloan.

${ }^{17}$ We count FENACOBU - The National Federation of COOPECs of Burundi (Fédération Nationale des COOPECS du Burundi.) as 1 MFI. We surveyed 12 COOPECs (COOPEC is a "savings and loans cooperative").

${ }^{18}$ Out of 84 officers from the non-profit MFIs, 42 are from COOPECs.

${ }^{19}$ The conditional logit model is also known in the literature as McFadden's choice model.
} 
for each attribute. Coefficients $\beta_{k c}$ are the population-common components and $\tilde{\beta}_{k c}$ are person-specific components.

Since the categories for many attributes can be naturally ordered, we also use a linear version of the model, discussed in subsection 4.6.

\subsection{Pooled Estimation and General Regularities}

We start with the basic estimation in which we neglect person-specific components: i.e., we estimate average marginal valuations for the whole population of the microloan officers. The econometric model simplifies to

$$
u=\sum_{k=1}^{9} \sum_{c=2}^{C_{k}} \beta_{k c} I_{x_{i k}=c}+\varepsilon_{j i}
$$

We summarize the main estimation results in Table 2. More details are provided in Appendix B.

Consider the impact of applicant characteristics on microloan allocation. The impact of these characteristics determines the fulfillment of the pro-social mission of microfinance.

First, our results suggest that age has a non-monotone effect on loan allocation: older are preferred to younger until their mid-thirties, yet applicants in their forties have lower chance than applicants in their thirties ${ }^{20}$. For instance, a 34-year old on average has a $6.3 \%$ higher chance of obtaining a microloan compared to an 18-year old, whereas a 44-year old has almost the same chances as an 18-year old.

The positive effect of age on the probability of getting a microloan can be attributed to increasing experience, skills, or, more generally, human capital accumulation. After reach-

\footnotetext{
${ }^{20}$ And compared to even younger people, 44 -year old seem to have lower chances, although the differences are not statistically significant even at the $10 \%$ level.
} 
Table 2: Estimated average marginal effects.

\begin{tabular}{c|c|c|c|c|c}
\hline \multicolumn{5}{c}{ Applicant's attributes } \\
\hline \multicolumn{2}{c|}{ Age } & \multicolumn{2}{c}{ Gender } & \multicolumn{2}{c}{ Poverty } \\
\hline 18 years & baseline & Man & baseline & Extremely poor & baseline \\
22 years & $.042+$ & Woman & .015 & Very poor & $.027+$ \\
27 years & $.044+$ & & & Poor & $.096^{* * *}$ \\
34 years & $.063^{*}$ & & & & \\
44 years & .013 & & & & \\
\hline \hline
\end{tabular}

\begin{tabular}{l|c|c|c|c|c}
\hline \hline \multicolumn{4}{c}{ Project attributes } \\
\hline $\begin{array}{l}\text { Quality of the project - prob. } \\
\text { of timely repaym. }\end{array}$ & \multicolumn{2}{|c|}{ Loan size } & \multicolumn{2}{c}{ Monitoring possibilities } \\
\hline Prob-1 & baseline & small & baseline & easy & baseline \\
Prob-2 & $.069^{* * *}$ & medium & $-.041^{* *}$ & some diff. & $-.044^{* *}$ \\
Prob-3 & $.115^{* * *}$ & large & $-.127^{* * *}$ & difficult & $-.092^{* * *}$ \\
Prob-4 & $.179^{* * *}$ & & & & \\
\hline \hline
\end{tabular}

\begin{tabular}{c|c|c|c|c|c}
\hline \hline \multicolumn{6}{c}{ Other characteristics } \\
\hline Household composition & \multicolumn{2}{|c}{ Accommodation size } & \multicolumn{2}{|c}{ Previous occup. } \\
\hline alone & baseline & 1 & baseline & student & baseline \\
couple & .003 & 2 & .013 & employed & $.128^{* * *}$ \\
$2+2$ ch. & .027 & 3 & .027 & unemployed & .024 \\
$2+2$ ch.+eld. & $-.055^{* *}$ & $3+$ & $.035+$ & & \\
\hline \hline$* * *-p<0.01,{ }^{* *}-p<0.05, *-p<0.1,+-p<0.2$ \\
\hline
\end{tabular}

ing their forties, people become more exposed to risks of interruption of entrepreneurial activity, e.g., health problems. Further, the fact that we observe a negative age effect for an age as low as forty can be related to the low average life expectancy in Burundi (50.4 years according to The World Bank (2010)).

Second, women do not seem to be preferred to men, holding other things equal.

Third, wealthier applicants have significantly higher chances of getting an application for a microloan approved. This finding is in line with the general trend in microfinance of reshaping the pattern of microloan allocation towards the less poor. This trend is a clear deviation from the initial pro-social mission of microfinance, but can be hard to avoid considering the pressure on MFIs to be financially viable. 
To sum up, it seems that on average Burundian microloan officers' preferences are not shaped by the pro-social mission of microfinance: neither the youngest nor the oldest clients are treated favorably, women do not have better chances, and, finally, wealthier applicants are preferred to the poorer, holding other things equal.

We will now turn to the analysis of the second group of attributes - project characteristics. This group of factors seems to be the most important determinant of microloan allocation.

First, microloan officers prefer the entrepreneurial projects of better quality with a higher perceived repayment rate. Second, applicants for smaller loans are preferred to applicants for larger ones. Third, more difficult monitoring reduces the chances of microloan granting.

For example, projects where the timely repayment is perceived to be almost certain have an average $18 \%$ higher chance of getting a loan than those with a $50 \%$ perceived probability of timely repayment. The applicants for large loans have a $12.7 \%$ lower chance of getting a loan compared to applicants for small loans. Finally, projects that are difficult to monitor have a $9.2 \%$ lower chance of being granted a microloan than projects that are easy to monitor.

Finally, consider the last group of applicant/project characteristics, which includes household composition, accommodation size, and prior occupation of the applicant.

Big families living with elderly people have a $5.5 \%$ lower chance of obtaining a microloan than other types of families (single, couples, couples with children). A natural explanation for this finding is that larger families are more likely to appear to be in financial distress, which decreases the chances of timely loan repayment. This finding is also in line with the hypothesis that older people have some bargaining power in the household, which can lead to inefficient use of the microloan, and, as a consequence, may 
increase the risk of delays in loan repayment.

Our analysis suggests that being employed increases the chance of obtaining a microloan by $12.8 \%$ compared to being a student. This finding supports the acquired human capital argument. Also, currently employed individuals may be considered to be more trustworthy.

The size of an accommodation seems to have a slight and weakly statistically significant effect: ${ }^{21}$ applicants with larger accommodations seem to have better chances of obtaining a microloan. This positive effect of accommodation size was expected since applicants with larger accommodations are likely to be perceived by microloan officers as having some collateralizable assets.

The analysis of the last group of characteristics suggests that microloan officers prefer to grant loans to applicants with more secure repayment prospects, rather than to the less advantaged, e.g., the poorest of the poor or women.

\subsection{Profit-Seeking vs. Non-Profit MFIs}

We will now assess the impact of type of MFI on the preferences of microloan officers. We proceed by estimating the econometric model

$$
u=\sum_{k=1}^{9} \sum_{c=2}^{C_{k}} \beta_{k c} I_{x_{i k}=c}+\sum_{k=1}^{9} \sum_{c=2}^{C_{k}} \tilde{\beta}_{k c} I_{x_{i k}=c}+\varepsilon_{j i}
$$

where $\tilde{\beta}_{j k c}=0$ if the microloan officer is employed by a non-profit MFI. Then the marginal valuations of applicant/project characteristics for the representative agent, employed by a non-profit MFI, are given by vector $\beta$, and for the representative agent, employed by profit-seeking MFI, are $\beta+\tilde{\beta}$. We will focus on the components of $\tilde{\beta}$ as they show the

\footnotetext{
${ }^{21}$ The result is significant only at the $17 \%$ level.
} 
differences between the two types of MFIs. The estimated marginal effects for the model are reported in Table 3, and the detailed estimation results are reported in Appendix C.

Table 3: Marginal effects of the model with MFI type effect.

\begin{tabular}{|c|c|c|c|}
\hline Attribute & Value & $\mathrm{dp} / \mathrm{dx}(\beta)$ & $\mathrm{dp} / \mathrm{dx}(\widetilde{\beta})$ \\
\hline Age & $\begin{array}{l}18 \text { years } \\
22 \text { years } \\
27 \text { years } \\
34 \text { years } \\
44 \text { years }\end{array}$ & $\begin{array}{c}\text { baseline } \\
.080441^{* * *} \\
.089011^{* * *} \\
.095532^{* * *} \\
.037321\end{array}$ & $\begin{array}{c}-.195268^{* * *} \\
-.215363^{* * *} \\
-.16196^{* *} \\
-.141738^{*}\end{array}$ \\
\hline Gender & $\begin{array}{c}\text { Man } \\
\text { Woman }\end{array}$ & $\begin{array}{l}\text { baseline } \\
.02267+\end{array}$ & $-.043296+$ \\
\hline Poverty & $\begin{array}{c}\text { Extremely poor } \\
\text { Very poor } \\
\text { Poor }\end{array}$ & $\begin{array}{c}\text { baseline } \\
.031172+ \\
.098812^{* * *}\end{array}$ & $\begin{array}{c}-.029486 \\
-.01178\end{array}$ \\
\hline $\begin{array}{l}\text { Quality of the } \\
\text { project - prob. of } \\
\text { timely reimburs. }\end{array}$ & $\begin{array}{l}\text { Prob-1 } \\
\text { Prob-2 } \\
\text { Prob-3 } \\
\text { Prob-4 }\end{array}$ & $\begin{array}{c}\text { baseline } \\
.073809^{* * *} \\
.131864^{* * *} \\
.182591^{* * *}\end{array}$ & $\begin{array}{c}-.021883 \\
-.065542 \\
.011995\end{array}$ \\
\hline Loan size & $\begin{array}{l}\text { small } \\
\text { medium } \\
\text { large }\end{array}$ & $\begin{array}{c}\text { baseline } \\
-.045458^{* *} \\
-.135975^{* * *}\end{array}$ & $\begin{array}{l}.012131 \\
.040038\end{array}$ \\
\hline Monitoring possibilities & $\begin{array}{c}\text { easy } \\
\text { with some difficulties } \\
\text { difficult }\end{array}$ & $\begin{array}{c}\text { baseline } \\
-.013084 \\
-.05536^{* * *}\end{array}$ & $\begin{array}{l}-.132491^{* * *} \\
-.160625^{* * *}\end{array}$ \\
\hline Household composition & $\begin{array}{c}\text { alone } \\
\text { couple } \\
2+2 \text { ch. } \\
2+2 \text { ch.+elderly } \\
\end{array}$ & $\begin{array}{c}\text { baseline } \\
-.013606 \\
.009826 \\
-.081447^{* * *} \\
\end{array}$ & $\begin{array}{l}.080144+ \\
.086468+ \\
.119648^{*} \\
\end{array}$ \\
\hline Accommodation size & $\begin{array}{c}1 \\
2 \\
3 \\
3+ \\
\end{array}$ & $\begin{array}{l}\text { baseline } \\
.020015 \\
.027641 \\
.030656\end{array}$ & $\begin{array}{c}-.021838 \\
-.007521 \\
.047701\end{array}$ \\
\hline Prev.occup. & $\begin{array}{c}\text { student } \\
\text { employed } \\
\text { unemployed }\end{array}$ & $\begin{array}{c}\text { baseline } \\
.110284^{* * *} \\
.035339+\end{array}$ & $\begin{array}{l}.095461^{* *} \\
-.043733\end{array}$ \\
\hline
\end{tabular}

Consider the impact of personal attributes of an applicant on microloan allocation. Our findings suggest that the youngest and the oldest applicants are the least preferred in both types of MFIs, yet the tendency is stronger for non-profit MFIs. This can be in some contradiction with the pro-social mission of microfinance since precisely the youngest and 
the oldest applicants are likely to have the most desperate need for financial support. On the other hand, loan allocation to the applicants in their twenties and thirties helps maintain financial viability.

Next, the preferences regarding microloan allocation to women seem to vary. Officers at non-profit MFIs' are slightly more predisposed to allocate loans to women (the result is significant only at the $16 \%$ level). This observation comes as a surprise given the extensively documented evidence that at least $70 \%$ of microloan borrowers in the world are women; see, e.g., Cull et al. (2007), D'Espallier et al. (2010). Women are targeted in microfinance mainly for two reasons: first, it is part of the pro-social mission of microfinance and second, women are generally better at paying off loans.

Finally, there is no significant difference with respect to the poverty level of the applicants. As mentioned, officers at both types of MFIs prefer to allocate loans to the less poor, which contradicts the social mission of microfinance, but, probably, is important for achieving financial viability.

These findings support the idea that competing MFIs with pro-social (non-profit) and profit objectives converge in their portfolio composition. This happens because the pro-social MFIs lose the possibility to cross-subsidize losses made on loans allocated to the most poor with gains from loans allocated to the less poor due to the competitive pressure from the profit-seeking MFIs.

We will now turn to the impact of project characteristics. The two types of MFIs differ only in the way the monitoring possibilities influence the preferences of microloan officers. However, this difference is very strong. Although the difficulties of monitoring decrease the chances of granting a loan in both types of MFIs, officers in profit-seeking MFIs are much more sensitive in this respect. For instance, in a non-profit MFI an applicant with a difficult-to-monitor project has a $5.5 \%$ lower chance of obtaining a microloan, as 
compared to an applicant with an easy-to-monitor project (holding other things equal): the corresponding difference in a profit-seeking MFI is $22 \%$ ! The different treatment of monitoring possibilities is one of the main differences in the preferences of microloan officers working in different types of MFIs in Burundi.

Note that the project quality, measured by the probability of timely loan repayment seen for similar types of projects, is equally important for microloan officers from both types of MFIs. All in all, it is definitely the most influential factor for microloans allocation.

Finally, let us consider the influence of other characteristics. Microloan officers in nonprofit MFIs dislike applicants with too big families (families, where not only children, but also elderly people live together), whereas officers from profit-seeking MFIs do not seem to mind this group of applicants. Regardless of type of MFI, officers prefer allocating loans to currently employed applicants, yet this preference is much stronger among officers from profit-seeking MFIs. Compared with an applicant who is currently a student, a currently employed applicant has an 11\% higher chance of obtaining a loan from a non-profit MFI and a $20 \%$ higher chance of obtaining a loan from a profit-seeking MFI.

To sum up, our findings suggest that when allocating microloans, microloan officers at both types of MFIs in Burundi first take into account factors conducive to financial viability. The fulfillment of the pro-social mission has some influence, for instance, microloan officers at non-profit MFIs have some predisposition to attribute loans to women. The officers in the two types of MFIs significantly differ in their valuation of project monitoring possibilities. 


\subsection{The Impact of Incentive Schemes in MFIs}

In this part of the paper we discuss the practices of using incentive schemes for microloan officers.

Table 4 summarizes our findings on the frequencies of using different types of incentive payments, broken down by type of MFI. ${ }^{22}$

Table 4: The frequency of the use of incentives in MFIs.

\begin{tabular}{|c|c|c|c|c|c|c|}
\hline \multirow{2}{*}{ MFI status } & \multicolumn{5}{|c|}{ Payment depends on ... } & \multirow{2}{*}{$\mathrm{N}$} \\
\cline { 2 - 7 } & money amount & outreach & repayment & poorest & women & \\
\hline \hline Profit-Seeking & .16 & .115 & .231 & .038 & .08 & $25-26$ \\
\hline non-profit & .123 & .257 & .187 & .110 & .125 & $72-75$ \\
\hline \hline Total & .133 & .22 & .198 & .091 & .113 & $97-101$ \\
\hline
\end{tabular}

Note that incentive payments are used only in a small share of the assessed MFIs. This implies that our estimation results for the impact of incentives should be treated only as suggestive due to the small size of the subsample on which the estimations are based.

It seems that non-profit and profit-seeking MFIs differ most in the use of incentives for outreach: $25 \%$ of the microloan officers from non-profit MFIs responded that the incentives are used in their MFIs, whereas only $11.5 \%$ of the microloan officers from profit-seeking MFIs reported that their MFIs use this kind of incentive.

Every fifth microloan officer has an incentive pay based on repayment rate. Non-profit and profit-seeking MFIs appear to be similar in this respect. Other types of incentives are used less frequently.

We report estimation results of the corresponding models, similar to (4), in Appendix

\footnotetext{
${ }^{22}$ More precisely, the question given to the respondents was "You are payed more by your MFI (in the form of salary or bonuses) if... a) you have distributed more money for microcredits; b) you have distributed microcredits to more people; c) the repayment rate for the credits allocated by you is higher; d) you have distributed more credit to the poorest people; e) you have allocated more credit to women."
} 
D. The only difference is that now the specific component $\tilde{\beta}$ takes non-zero values for the officers, reported that their wage (including bonuses) is affected by a particular type of incentive. We estimate five models that correspond to each type of incentive.

When the payment to a microloan officer depends on the amount of allocated money, it has a strong positive effect on the marginal valuation of allocating large-size loans, which is probably the easiest way to achieve the goal of increasing the allocated money.

Introduction of incentive pay based on outreach seems to lead to an increase in the marginal valuation of allocating loans to women and old applicants ${ }^{23}$. This result suggests that microloan officers consider these two groups to be "on the margin" for microloan allocation in the sense that these applicants will be the first to obtain microloans would microfinance expand its scope. This finding also suggests that microloan officers consider other applicants as "already covered" with microloans.

Microloan officers provided with incentives based on repayment rate do not value the probability of timely repayment to a large degree, which seems surprising. Yet, it suggests that the probability of timely repayment is already taken into account by all microloan officers, independently of whether it is incentivized or not.

Introduction of incentives based on allocation of the loans to the poorest leads, as expected, to more favorable treatment of the poorest, but simultaneously increases the marginal valuation of monitoring possibilities. This suggests that microloan officers tend to compensate loan allocation to the poorest, who are known to have difficulties making timely payment, to some extent, due to poor organization of their entrepreneurial projects, through tighter control and monitoring to ensure that the money will be used properly and revenues required for loan repayment will be acquired.

Finally, as expected, if the pay to the microloan officer increases with the share of

\footnotetext{
${ }^{23}$ This corresponds to the category of 44 -year old in our experiment.
} 
women in the pool of borrowers, it increases the valuation of allocating loans to women.

To sum up, we obtained evidence that monetary incentives do influence the valuations of microloan officers for allocating loans to applicants with targeted characteristics in the expected way. At the same time, incentives targeting a particular applicant-project characteristic may induce changes in the marginal valuations of other characteristics related to the targeted ones.

\subsection{Robustness Checks}

Here we present the results of a number of robustness checks. They are based on the different representations of choice sets and on different estimation techniques.

First, consider the effect of the order in which the attributes were presented. In the choice experiment we used two alternative orders, as shown in Table 5.

Table 5: The alternative orderings of attributes.

\begin{tabular}{|l|l|}
\hline Presentation order $\mathbf{1}$ & Presentation order 2 \\
\hline \hline Age & Loan size \\
\hline Gender & Difficulty of monitoring \\
\hline Poverty level & Last occupation \\
\hline $\begin{array}{l}\text { Probability of timely repayment for the sim- } \\
\text { ilar type of projects }\end{array}$ & Age \\
\hline Number of persons in the household & Gender \\
\hline Accommodation size & Poverty level \\
\hline Last occupation & Accommodation size \\
\hline Loan size & Number of persons in the household \\
\hline Difficulty of monitoring & $\begin{array}{l}\text { Probability of timely repayment for the sim- } \\
\text { ilar type of projects }\end{array}$ \\
\hline
\end{tabular}

To estimate the "order of presentation effect" on the choices of the microloan officers, we estimate the model of the form (4) with $\tilde{\beta}$ taking non-zero values for the second presentation order. 
The estimation results are reported in Appendix E. It is worth noting that some attributes seem to have a stronger effect if presented at the very top or very bottom of the list of attributes. For instance, when the probability of timely repayment for the similar type of projects is presented at the very bottom of the list (presentation order 2), it has a stronger impact on the estimates of valuation of it. We also note that there is a similar effect for the difficulty of monitoring, i.e., when presented at the very bottom of the list, it seems to have a stronger effect on marginal valuations, although the result is significant only at the $20 \%$ level.

Overall, these results suggest that the impact of order of presentation does not alter our main findings qualitatively. At the same time, we report evidence that in general, when designing and analyzing results of choice experiment, attribute presentation order should be taken into account.

Second, consider different error specifications. We have re-estimated the baseline model ("pooled estimation") with robust standard errors and with bootstrap; the results are reported in Appendix E. There are only marginal changes in the re-estimated standard errors. So, our results are robust to changing assumptions on the error terms.

Third, consider the alternative model specification. Since the categorical values for all attributes except one (last occupation) can be naturally ordered, we consider utility depending on the attributes' categories in the linear form. However, previous analysis suggests that two exceptions should be made. First, since we have found a non-monotone effect of age, we consider age categories entering in the empirical model linearly up to age 34 (categories 1-4) and include the indicator variable for 44 years. Second, we include indicator variables for the categories, corresponding to the prior occupation of the 
applicant as they can't be ordered. This leads to the following econometric specification:

$$
u=\sum_{k=1}^{8} \beta_{k} X_{k}+\beta_{15} I_{A g e=44}+\beta_{92} I_{X_{9}=2}+\beta_{93} I_{X_{9}=3}+\varepsilon
$$

where variables $X_{k}$ take the values $1, \ldots, C_{k}$ (naturally, $X_{1}$, which corresponds to age, takes the values $1, \ldots, 4$ or 0 if age $=44$ years).

The estimation results are reported in Appendix E. The results support our findings for the main model with categorical variables.

Overall, the robustness checks suggest that although we have found that the attribute presentation order affects the estimated attributes valuations, it does not alter our findings qualitatively. Our results are robust to changes in the model specification.

\section{Concluding Remarks}

This paper reports the results of a field study aimed at identifying the determinants of microloan allocation linked to the internal structure of an MFI. Specifically, we study preferences of microloan officers over microloans allocation as well as factors influencing these preferences. We focus on microloan officers since they directly contact the applicants and give recommendations concerning loan provision. Even if in many MFIs the officers do not make the final decisions, they certainly have an important influence on these decisions as they are the key information processing actors.

The choice of Burundi for the study is conscious. The country has a unique background: Burundi was devastated by a civil war that lasted from 1993 to 2005. During this period, the country was not attractive for foreign investors and, unlike many other countries in the developing world, has not benefited much from the donors that tradi- 
tionally have supported the development of microfinance. Nevertheless, many MFIs in Burundi operated during the difficult period of war and were exposed to the requirement of financial viability to a much larger degree than MFIs in other countries. Moreover, non-profit and profit-seeking MFIs in Burundi have coexisted for a long time.

This path of microfinance development in Burundi is in fact parallel to the global trend in microfinance, characterized by shifting more and more toward self-sustainable development, which inevitably leads to partial commercialization and coexistence of nonprofit and profit-seeking microfinance (see Cull et al. (2007)). Because of this, the lessons that can be drawn from understanding the practices of microfinance in Burundi can be relevant for the development of microfinance in general.

By means of a choice experiment, we reveal preferences of loan officers over microloan allocation and differences between non-profit seeking and non-profit MFIs in Burundi. As argued above, these preferences shape microloan allocation. Our findings suggest that the two types of MFIs in Burundi do not differ much in terms of microloan allocation patterns, which is in line with the overall global trend of convergence of different types of MFIs.

We found that the main determinants of microloan attribution for both types of MFIs in Burundi are related to the quality of the entrepreneurial project, for which the microloan is applied. More exactly, these determinants are: expected probability of timely loan repayment, loan size, and monitoring possibilities. However, our results suggest that the impact of monitoring possibilities differ significantly. Specifically, officers at profit-seeking MFIs are more sensitive to it.

Understanding the difference in valuations of project/applicant attributes between microloan officers from different types of MFIs is beyond the scope of our study, yet is definitely very important as these differences may drive differences in loan allocation 
patterns between the two types of MFIs. We can only make some suggestions on why the differences can emerge.

Careful monitoring requires higher cost, mainly, for labor and transportation. It could be the case that if an MFI experiences limitations with respect to operational costs, then less attention to monitoring possibilities can be paid since these budgeting limitations may hamper careful monitoring. Non-profit MFIs are more likely to be exposed to the budget limitations by their very nature, as profit-making is not their objective. As a result, although MFI management and microloan officers recognize that monitoring is essential, it could play only a limited role in shaping microloan allocation when an MFI should take into account limitations on operational costs.

Since monitoring leads to increased sustainability, the difference in valuation of monitoring possibilities leads to losses in operational efficiency in non-profit MFIs. This observation should raise a concern for the management and supporters of MFIs and inplies that MFIs, especially those supported by donors, should have flexibility to adjust operational costs and improve efficiency. Otherwise, they risk entering a vicious cycle: restrictions on operational costs lead to insufficient monitoring, which, in turn, adversely affects financial sustainability and can impose further restrictions on operational costs.

Another important finding of our study is that the incentives, provided to microloan officers seem to work in the right direction: microloan officers place a higher value on loans to groups targeted by incentive scheme. At the same time, we note that incentive payments are only rarely used in Burundi. However, during the interviews with the management of the studied MFIs, many of them acknowledged that they would consider introducing incentive payments.

Our results suggest that a properly designed incentive structure can positively influence the performance of microloan officers, since they tend to respond by allocating more 
loans to the targeted group of applicants ${ }^{24}$. At the same time, incentives targeted to a particular characteristic of the potential borrower can have side effects on the valuations of other characteristics, which should be taken into account when designing incentives.

This paper will hopefully stimulate further investigations into modeling MFI organizational structures or even serve as a basis for empirical justification of such research efforts.

\footnotetext{
${ }^{24}$ The targeted group can either be targeted from a social perspective, e.g., the poorest or women, or be targeted from the perspective of financial viability, e.g., applicants with entrepreneurial projects of high quality.
} 


\section{APPENDIX}

\section{A Answer Sheet for the Choice Experiment}

Compare the 2 candidats:

\begin{tabular}{|c|c|c|}
\hline & Candidat 1 & Candidat 2 \\
\hline Age & 27 years & 22 years \\
\hline Gender & Woman & Man \\
\hline Poverty level & poor & Very poor \\
\hline $\begin{array}{l}\text { Timely repayment for the } \\
\text { similar type of projects... }\end{array}$ & $\begin{array}{l}\text { In half } \\
\text { of the } \\
\text { cases }\end{array}$ & $\begin{array}{l}\text { In half } \\
\text { of the } \\
\text { cases }\end{array}$ \\
\hline Household composition & Married with 2 children & Living alone \\
\hline Accomodation type & Accomodation with 2 pieces & Accomodation with 1 piece \\
\hline Last occupation & unemployed & Student \\
\hline Size of the loan & Small size & Big size \\
\hline Difficulty of monitoring & difficult & With some difficulties \\
\hline $\begin{array}{r}\text { Choose one candidat for the loan } \\
\text { attribution }\end{array}$ & 1 & 2 \\
\hline How sure you are? & $\begin{array}{r}\text { surely } \\
\text { for } 1\end{array}$ & $\begin{array}{r}\text { surely } \\
\text { for } 2\end{array}$ \\
\hline
\end{tabular}

\section{FRENCH VERSION (AS USED IN THE FIELD)}

Comparez les 2 candidats:

\begin{tabular}{|c|c|c|}
\hline & Candidat 1 & Candidat 2 \\
\hline Age & 27 ans & 22 ans \\
\hline Sexe & Femme & Homme \\
\hline Niveau de Pauvreté & pauvre & très pauvre \\
\hline $\begin{array}{l}\text { Remboursement à temps pour } \\
\text { les mêmes types de projets... }\end{array}$ & $\begin{array}{l}\text { dans la } \\
\text { moitié } \\
\text { descas }\end{array}$ & $\begin{array}{l}\text { dans la } \\
\text { moitié } \\
\text { des cas }\end{array}$ \\
\hline $\begin{array}{l}\text { Nombre de personnes dans le } \\
\text { foyer }\end{array}$ & marié(e), avec 2 enfants & seule \\
\hline Type de logement & logement avec 2 pieces & logement avec 1 piece \\
\hline Dernier poste occupé & sans travail & étudiant(e) \\
\hline Montant du prêt & de petite taille & de grande taille \\
\hline $\begin{array}{l}\text { La difficulté de suivi } \\
\text { (monitoring) }\end{array}$ & difficile & avec qeulques difficultés \\
\hline $\begin{array}{r}\text { Choisissez un candidat pour } \\
\text { l'attribution de prêts }\end{array}$ & 1 & 2 \\
\hline Quelle est Votre certitude? & $\begin{array}{l}\text { sûrement } \\
\text { pour } 1\end{array}$ & $\begin{array}{l}\text { sûrement } \\
\text { pour } 2\end{array}$ \\
\hline
\end{tabular}




\section{B Pooled Regression}

Table 6: Marginal Effects for the Pooled Estimation.

\begin{tabular}{|c|c|c|c|c|c|}
\hline Attribute & Value & $\mathrm{dp} / \mathrm{dx}$ & std.err. & $\overline{Z Z}$ & $P>z$ \\
\hline Age & $\begin{array}{l}18 \text { years } \\
22 \text { years } \\
27 \text { years } \\
34 \text { years } \\
44 \text { years }\end{array}$ & $\begin{array}{c}\text { baseline } \\
.042254+ \\
.04415+ \\
.063094^{*} \\
.013061\end{array}$ & $\begin{array}{l}.027266 \\
.029944 \\
.032582 \\
.030307\end{array}$ & $\begin{array}{l}1.55 \\
1.47 \\
1.94 \\
0.43\end{array}$ & $\begin{array}{l}0.121 \\
0.140 \\
0.053 \\
0.667\end{array}$ \\
\hline Gender & $\begin{array}{c}\text { Man } \\
\text { Woman }\end{array}$ & $\begin{array}{c}\text { baseline } \\
.014916\end{array}$ & .012487 & 1.19 & 0.23 \\
\hline Poverty & $\begin{array}{c}\text { Extremely poor } \\
\text { Very Poor } \\
\text { Poor }\end{array}$ & $\begin{array}{c}\text { baseline } \\
.026856+ \\
.095814^{* * *}\end{array}$ & $\begin{array}{l}.018533 \\
.018819\end{array}$ & $\begin{array}{l}1.45 \\
5.09\end{array}$ & $\begin{array}{l}0.147 \\
0.000\end{array}$ \\
\hline $\begin{array}{l}\text { Quality of the } \\
\text { project - prob. of } \\
\text { timely repaym. }\end{array}$ & $\begin{array}{l}\text { Prob-1 } \\
\text { Prob-2 } \\
\text { Prob-3 } \\
\text { Prob-4 }\end{array}$ & $\begin{array}{c}\text { baseline } \\
.06897^{* * *} \\
.114571^{* * *} \\
.17874^{* * *}\end{array}$ & $\begin{array}{l}.023016 \\
.02269 \\
.021799\end{array}$ & $\begin{array}{c}3.00 \\
5.05 \\
8.2\end{array}$ & $\begin{array}{l}0.003 \\
0.000 \\
0.000\end{array}$ \\
\hline Loan size & $\begin{array}{l}\text { Small } \\
\text { Medium } \\
\text { Large }\end{array}$ & $\begin{array}{c}\text { baseline } \\
-.040902^{* *} \\
-.126588^{* * *}\end{array}$ & $\begin{array}{c}.018101 \\
.01805\end{array}$ & $\begin{array}{l}-2.26 \\
-7.01\end{array}$ & $\begin{array}{l}0.024 \\
0.000\end{array}$ \\
\hline Monitoring possibilities & $\begin{array}{c}\text { Easy } \\
\text { With some diff. } \\
\text { Difficult }\end{array}$ & $\begin{array}{c}\text { baseline } \\
-.044461^{* *} \\
-.091768^{* * *}\end{array}$ & $\begin{array}{l}.017532 \\
.018247\end{array}$ & $\begin{array}{l}-2.54 \\
-5.03\end{array}$ & $\begin{array}{l}0.011 \\
0.000\end{array}$ \\
\hline Household composition & $\begin{array}{c}\text { Alone } \\
\text { Couple } \\
2+2 \text { ch. } \\
2+2 \text { ch.+eld. }\end{array}$ & $\begin{array}{c}\text { baseline } \\
.003262 \\
.026718 \\
-.054462^{* *} \\
\end{array}$ & $\begin{array}{c}.02168 \\
.024549 \\
.02768 \\
\end{array}$ & $\begin{array}{c}0.15 \\
1.09 \\
-1.97 \\
\end{array}$ & $\begin{array}{l}0.880 \\
0.276 \\
0.049 \\
\end{array}$ \\
\hline Accommodation size & $\begin{array}{c}1 \text { piece } \\
2 \text { pieces } \\
3 \text { pieces } \\
3+\text { pieces }\end{array}$ & $\begin{array}{l}\text { baseline } \\
.012882 \\
.026265 \\
.034948+\end{array}$ & $\begin{array}{l}.020205 \\
.024431 \\
.025571\end{array}$ & $\begin{array}{l}0.64 \\
1.08 \\
1.37\end{array}$ & $\begin{array}{l}0.524 \\
0.282 \\
0.172\end{array}$ \\
\hline Prev.occup. & $\begin{array}{c}\text { Student } \\
\text { Employed } \\
\text { Unemployed }\end{array}$ & $\begin{array}{c}\text { baseline } \\
.127636^{* * *} \\
.023351\end{array}$ & $\begin{array}{l}.019131 \\
.020489\end{array}$ & $\begin{array}{l}6.67 \\
1.14\end{array}$ & $\begin{array}{l}0.000 \\
0.254\end{array}$ \\
\hline
\end{tabular}




\section{MFI type effects}

Table 7: Marginal Effects for the Model with MFI Type Effects.

\begin{tabular}{|c|c|c|c|c|c|c|c|c|c|}
\hline \multirow[b]{2}{*}{ Attribute } & \multirow[b]{2}{*}{ Value } & \multicolumn{4}{|c|}{ בCommon component $(\beta)$} & \multicolumn{4}{|c|}{ Profit-seeking MFI-specific $(\tilde{\beta})$} \\
\hline & & $\mathrm{dp} / \mathrm{dx}$ & s.e. & $\mathrm{Z}$ & $P>z$ & $\mathrm{dp} / \mathrm{dx}$ & s.e. & $\mathrm{z}$ & $P>z$ \\
\hline Age & $\begin{array}{l}18 \text { years } \\
22 \text { years } \\
27 \text { years } \\
34 \text { years } \\
44 \text { years }\end{array}$ & $\begin{array}{c}\text { baseline } \\
.080^{* * *} \\
.089^{* * *} \\
.096^{* * *} \\
.037\end{array}$ & $\begin{array}{l}.030 \\
.034 \\
.037 \\
.034 \\
\end{array}$ & $\begin{array}{c}2.66 \\
2.64 \\
2.62 \\
-1.09 \\
\end{array}$ & $\begin{array}{l}0.008 \\
0.008 \\
0.009 \\
0.275 \\
\end{array}$ & $\begin{array}{l}-.195^{* * *} \\
-.215^{* * *} \\
-.162^{* *} \\
-.142^{*} \\
\end{array}$ & $\begin{array}{l}.063 \\
.066 \\
.076 \\
.073 \\
\end{array}$ & $\begin{array}{l}-3.12 \\
-3.29 \\
-2.12 \\
-1.94 \\
\end{array}$ & $\begin{array}{l}0.002 \\
0.001 \\
0.034 \\
0.052 \\
\end{array}$ \\
\hline Gender & $\begin{array}{c}\text { Man } \\
\text { Woman }\end{array}$ & $\begin{array}{c}\text { baseline } \\
.023+\end{array}$ & .014 & -1.59 & 0.112 & $-.043+$ & .031 & -1.41 & 0.159 \\
\hline Poverty & $\begin{array}{c}\text { Extremely poor } \\
\text { Very poor } \\
\text { Poor }\end{array}$ & $\begin{array}{c}\text { baseline } \\
.031+ \\
.099^{* * *}\end{array}$ & $\begin{array}{l}.021 \\
.022 \\
\end{array}$ & $\begin{array}{l}1.45 \\
4.60 \\
\end{array}$ & $\begin{array}{l}0.146 \\
0.000 \\
\end{array}$ & $\begin{array}{l}-.030 \\
-.012 \\
\end{array}$ & $\begin{array}{l}.045 \\
.050\end{array}$ & $\begin{array}{l}-0.65 \\
-0.24 \\
\end{array}$ & $\begin{array}{l}0.514 \\
0.813 \\
\end{array}$ \\
\hline $\begin{array}{l}\text { Quality of the } \\
\text { project }\end{array}$ & $\begin{array}{l}\text { Prob-1 } \\
\text { Prob-2 } \\
\text { Prob-3 } \\
\text { Prob-4 }\end{array}$ & $\begin{array}{l}\text { baseline } \\
.074^{* * *} \\
.132^{* * *} \\
.183^{* * *}\end{array}$ & $\begin{array}{l}.027 \\
.026 \\
.025\end{array}$ & $\begin{array}{l}2.77 \\
5.15 \\
7.31\end{array}$ & $\begin{array}{l}0.006 \\
0.000 \\
0.000\end{array}$ & $\begin{array}{l}-.022 \\
-.066 \\
.012\end{array}$ & $\begin{array}{l}.056 \\
.061 \\
.064\end{array}$ & $\begin{array}{c}-0.39 \\
-1.08 \\
0.19\end{array}$ & $\begin{array}{l}0.695 \\
0.280 \\
0.852\end{array}$ \\
\hline Loar & $\begin{array}{l}\text { Small } \\
\text { Medium } \\
\text { Large }\end{array}$ & $\begin{array}{l}\text { baseline } \\
-.046^{* *} \\
-.136^{* * *}\end{array}$ & $\begin{array}{l}.021 \\
.021 \\
\end{array}$ & $\begin{array}{l}-2.20 \\
-6.63\end{array}$ & $\begin{array}{l}0.028 \\
0.000\end{array}$ & $\begin{array}{l}.012 \\
.040\end{array}$ & $\begin{array}{l}.045 \\
.046\end{array}$ & $\begin{array}{l}0.27 \\
0.88\end{array}$ & $\begin{array}{l}0.789 \\
0.379 \\
\end{array}$ \\
\hline $\begin{array}{l}\text { Monitoring } \\
\text { possibilities }\end{array}$ & $\begin{array}{c}\text { Easy } \\
\text { With some diff. } \\
\text { Difficult }\end{array}$ & $\begin{array}{l}\text { baseline } \\
-.013 \\
-.055^{* * *}\end{array}$ & $\begin{array}{l}.020 \\
.021\end{array}$ & $\begin{array}{l}-0.64 \\
-2.61\end{array}$ & $\begin{array}{l}0.522 \\
0.009\end{array}$ & $\begin{array}{l}-.133^{* * *} \\
-.161^{* * *}\end{array}$ & $\begin{array}{l}.043 \\
.043\end{array}$ & $\begin{array}{l}-3.11 \\
-3.74\end{array}$ & $\begin{array}{l}0.002 \\
0.000\end{array}$ \\
\hline $\begin{array}{l}\text { Household } \\
\text { composition }\end{array}$ & $\begin{array}{c}\text { Alone } \\
\text { Couple } \\
2+2 \text { ch. } \\
\text { 2+2ch.+eld. }\end{array}$ & $\begin{array}{c}\text { baseline } \\
-.014 \\
.010 \\
-.081^{* * *} \\
\end{array}$ & $\begin{array}{l}.025 \\
.028 \\
.032\end{array}$ & $\begin{array}{l}-0.55 \\
0.35 \\
-2.57\end{array}$ & $\begin{array}{l}0.585 \\
0.728 \\
0.010 \\
\end{array}$ & $\begin{array}{l}.080+ \\
.086+ \\
.120^{*}\end{array}$ & $\begin{array}{l}.052 \\
.057 \\
.062\end{array}$ & $\begin{array}{l}1.54 \\
1.51 \\
1.91\end{array}$ & $\begin{array}{l}0.124 \\
0.131 \\
0.055\end{array}$ \\
\hline $\begin{array}{l}\text { Accommodation } \\
\text { size }\end{array}$ & $\begin{array}{c}1 \text { piece } \\
2 \text { pieces } \\
3 \text { pieces } \\
3+\text { pieces }\end{array}$ & $\begin{array}{c}\text { baseline } \\
.020 \\
.028 \\
.031\end{array}$ & $\begin{array}{l}.023 \\
.028 \\
.029\end{array}$ & $\begin{array}{l}0.85 \\
0.98 \\
1.05\end{array}$ & $\begin{array}{l}0.394 \\
0.327 \\
0.296\end{array}$ & $\begin{array}{l}-.022 \\
-.008 \\
.048\end{array}$ & $\begin{array}{l}.049 \\
.060 \\
.064\end{array}$ & $\begin{array}{c}-0.44 \\
-0.12 \\
0.75\end{array}$ & $\begin{array}{l}0.658 \\
0.901 \\
0.453\end{array}$ \\
\hline Prev.occup. & $\begin{array}{c}\text { Student } \\
\text { Employed } \\
\text { Unemployed }\end{array}$ & $\begin{array}{c}\text { baseline } \\
.110^{* * *} \\
.035+\end{array}$ & $\begin{array}{l}.022 \\
.023\end{array}$ & $\begin{array}{l}4.94 \\
1.51\end{array}$ & $\begin{array}{l}0.000 \\
0.131\end{array}$ & $\begin{array}{c}.095^{* *} \\
-.044\end{array}$ & $\begin{array}{l}.047 \\
.051\end{array}$ & $\begin{array}{c}2.03 \\
-0.86\end{array}$ & $\begin{array}{l}0.042 \\
0.391\end{array}$ \\
\hline
\end{tabular}




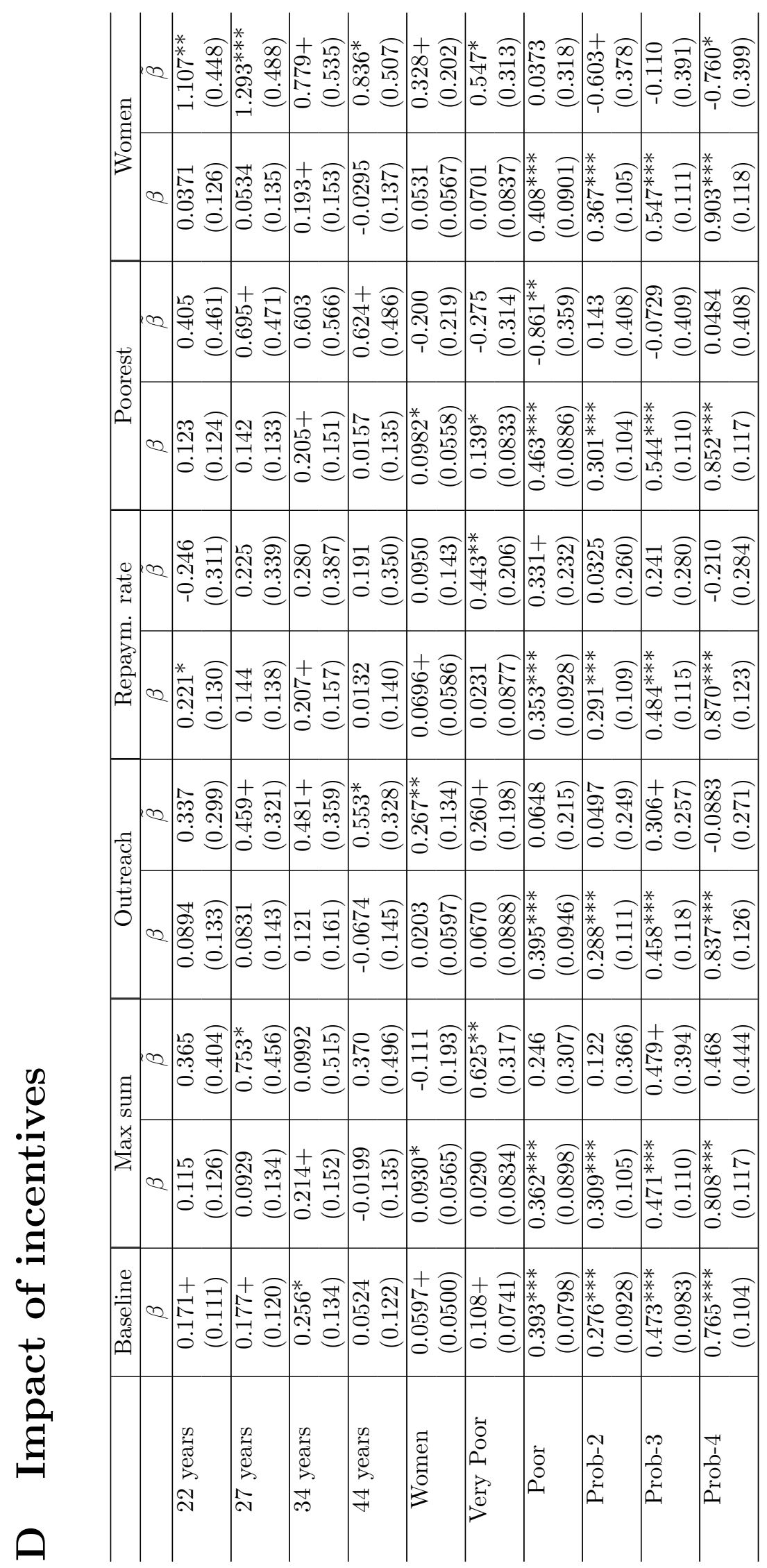




\begin{tabular}{|c|c|c|c|c|c|c|c|c|c|c|c|c|c|}
\hline & \& & 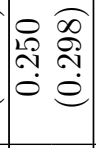 & 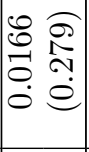 & 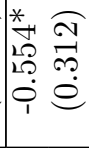 & 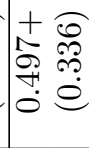 & 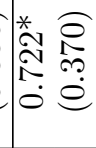 & 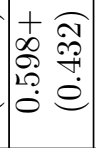 & 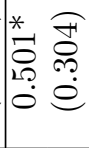 & 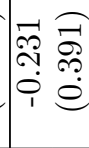 & $\begin{array}{l}1 \\
\infty \\
0 \\
0 \\
1 \\
1\end{array}$ & 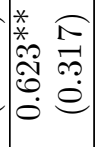 & 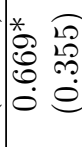 & \\
\hline & 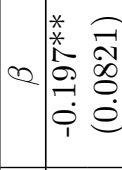 & $\mid \begin{array}{ll}* & \widehat{*} \\
* & 2 \\
0 & 2 \\
0 & 0 \\
10 & 0 \\
0 & 0 \\
0 & 0 \\
1 & 0 \\
\end{array}$ & $\left|\begin{array}{ll}\infty & - \\
\infty & 0 \\
-1 & 0 \\
0 & 0 \\
1 & 0\end{array}\right|$ & 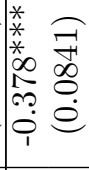 & . & {$\left[\begin{array}{ll}0 & 9 \\
0 & 7 \\
0 & 7 \\
0 & 5\end{array}\right.$} & 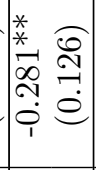 & $\begin{array}{l}0 \\
0 \\
0 \\
0 \\
1 \\
1\end{array}$ & $\ddot{\circ}$ & & & : & 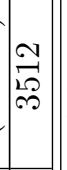 \\
\hline$y$ & 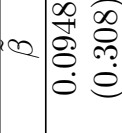 & 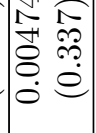 & 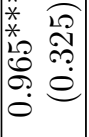 & 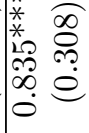 & & 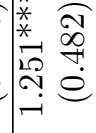 & {$\left[\begin{array}{ll}\widetilde{a} & \overline{0} \\
0 & 10 \\
0 & \stackrel{0}{0}\end{array}\right.$} & & 0 & & & & \\
\hline & 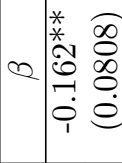 & 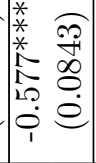 & 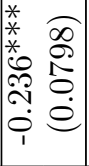 & 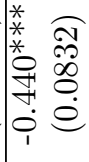 & 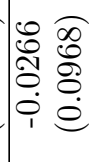 & 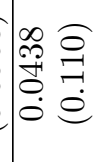 & 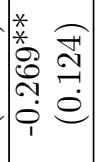 & & & & 10 & $\begin{array}{l}1 \\
0 \\
0 \\
0\end{array}$ & $\mid$ \\
\hline 营 & r. & 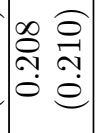 & 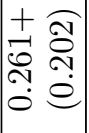 & 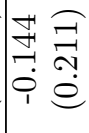 & 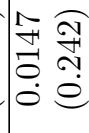 & 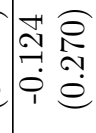 & 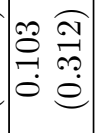 & & $\dot{0}$ & $\hat{c}_{1}^{0} e$ & & 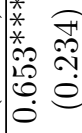 & \\
\hline حص & 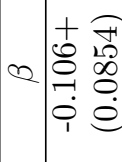 & 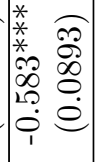 & 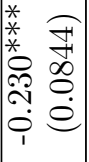 & 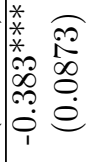 & & {$\left[\begin{array}{cc}1 & 0 \\
0 & 0 \\
\hdashline & \ddots \\
0 & 0\end{array}\right.$} & 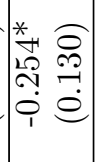 & 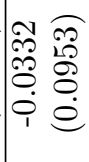 & & 苑 & & 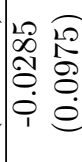 & 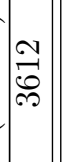 \\
\hline 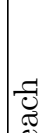 & 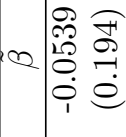 & 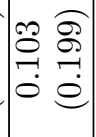 & 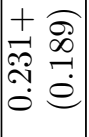 & 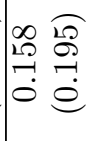 & 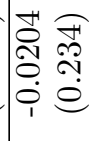 & 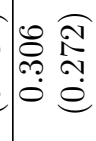 & 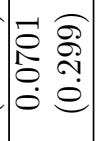 & 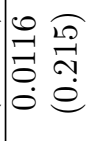 & 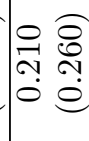 & 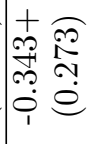 & & 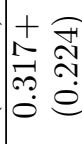 & \\
\hline 0 & 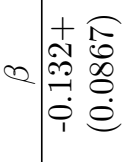 & 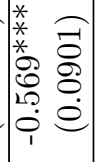 & 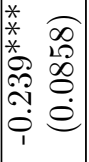 & 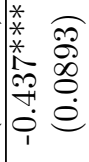 & : & 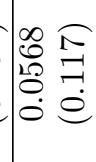 & 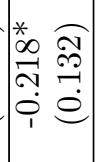 & 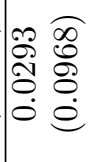 & $\mid \begin{array}{ll}\infty & \infty \\
0 & = \\
0 & \ddots \\
0 & 0 \\
0 & 0\end{array}$ & 齐 & & 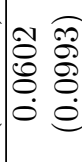 & 象 \\
\hline g & 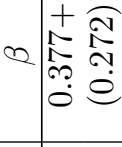 & 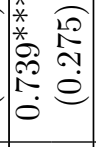 & $\left|\begin{array}{cc}0 & 0 \\
0 & 0 \\
\hdashline & 0 \\
0 & 0 \\
1 & 0 \\
& 0\end{array}\right|$ & 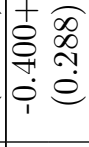 & $\dot{\varphi} \leqslant$ & 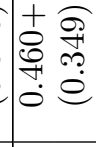 & 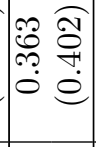 & 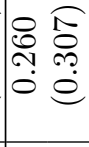 & 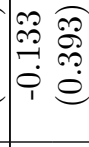 & 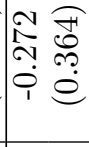 & & 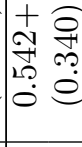 & \\
\hline 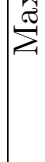 & $\Omega \mid \begin{array}{ll}* & \overparen{\sigma} \\
* & \sigma \\
\infty & \infty \\
0 & 0 \\
\dot{1} & 0 \\
1 & 0\end{array}$ & 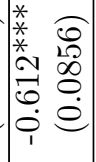 & 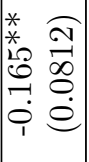 & 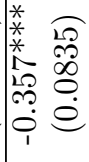 & 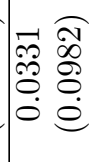 & 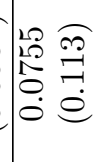 & 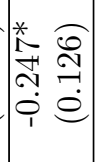 & \begin{tabular}{ll}
$\infty$ & $\widehat{\sigma}$ \\
\hdashline & $\sigma$ \\
0 & 0 \\
0 & 0 \\
1 & 0
\end{tabular} & $\mid \begin{array}{ll}20 & 0 \\
\stackrel{2}{0} & \ddots \\
0 & \ddots \\
0 & 0\end{array}$ & $\begin{array}{l}+1 \\
0 \\
0 \\
7 \\
0 \\
0 \\
0\end{array}$ & 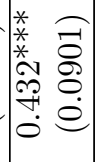 & $\begin{array}{l}0 \\
0 \\
0 \\
0 \\
0 \\
0\end{array}$ & 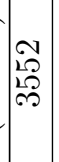 \\
\hline 疋 & 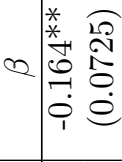 & 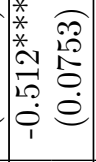 & \begin{tabular}{ll}
$*$ & 0 \\
$*$ & 10 \\
0 & $\stackrel{1}{1}$ \\
0 & 5 \\
\hdashline & 0 \\
0 & 0 \\
1 & 0
\end{tabular} & 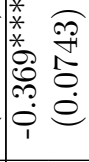 & $\mid \begin{array}{ll}\overrightarrow{1} & \stackrel{?}{0} \\
3 & 0 \\
0 & 0 \\
0 & 0 \\
0 & 0\end{array}$ & {$\left[\begin{array}{ll}1 & \widehat{A} \\
0 & 0 \\
\hdashline & 0 \\
0 & 0 \\
0\end{array}\right.$} & 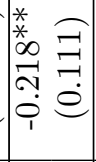 & $\begin{array}{ll}0 & \widehat{\partial} \\
10 & 0 \\
0 & 0 \\
0 & 0\end{array}$ & 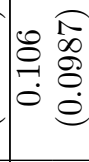 & 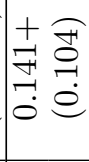 & 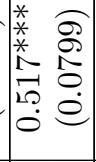 & 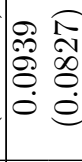 & \& \\
\hline & : & 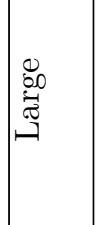 & 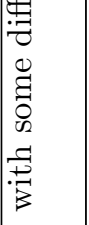 & 苞 & 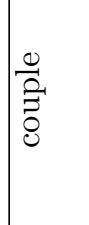 & $\begin{array}{l}\mathcal{d} \\
\stackrel{N}{N} \\
+ \\
\sim\end{array}$ & $\begin{array}{l}\overrightarrow{0} \\
+ \\
\dot{0} \\
\stackrel{0}{N} \\
+ \\
+1\end{array}$ & 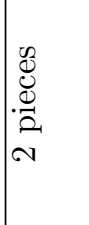 & 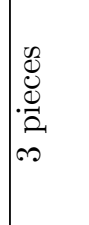 & 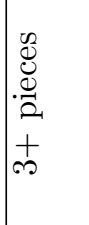 & 范 & 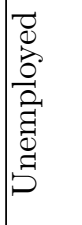 & 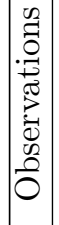 \\
\hline
\end{tabular}




\section{E Robustness Check}

\section{Estimation results for the model with the presentation order effects}

\begin{tabular}{|c|c|c|c|}
\hline \multirow{2}{*}{ Variable } & Baseline & \multicolumn{2}{|c|}{ Presentation order } \\
\hline & $\beta$ & $\beta$ & $\bar{\beta}$ \\
\hline 22 years & $\begin{array}{l}0.171+ \\
(0.111)\end{array}$ & $\begin{array}{l}0.186+ \\
(0.151)\end{array}$ & $\begin{array}{c}-0.0193 \\
(0.226)\end{array}$ \\
\hline 27 years & $\begin{array}{l}0.177+ \\
(0.120)\end{array}$ & $\begin{array}{l}0.193+ \\
(0.163)\end{array}$ & $\begin{array}{c}-0.00524 \\
(0.244)\end{array}$ \\
\hline 34 years & $\begin{array}{c}0.256^{*} \\
(0.134)\end{array}$ & $\begin{array}{l}0.247+ \\
(0.185)\end{array}$ & $\begin{array}{c}0.0548 \\
(0.273)\end{array}$ \\
\hline 44 years & $\begin{array}{c}0.0524 \\
(0.122)\end{array}$ & $\begin{array}{c}0.104 \\
(0.169)\end{array}$ & $\begin{array}{c}-0.0824 \\
(0.247)\end{array}$ \\
\hline Women & $\begin{array}{l}0.0597+ \\
(0.0500)\end{array}$ & $\begin{array}{c}0.0393 \\
(0.0678)\end{array}$ & $\begin{array}{c}0.0413 \\
(0.102)\end{array}$ \\
\hline Very Poor & $\begin{array}{c}0.108+ \\
(0.0741)\end{array}$ & $\begin{array}{c}0.186^{*} \\
(0.102)\end{array}$ & $\begin{array}{l}-0.169 \\
(0.150)\end{array}$ \\
\hline Poor & $\begin{array}{c}0.393^{* * *} \\
(0.0798)\end{array}$ & $\begin{array}{c}0.413^{* * *} \\
(0.109)\end{array}$ & $\begin{array}{c}-0.0149 \\
(0.162)\end{array}$ \\
\hline Prob-2 & $\begin{array}{c}0.276^{* * *} \\
(0.0928)\end{array}$ & $\begin{array}{c}0.212^{*} \\
(0.126)\end{array}$ & $\begin{array}{c}0.175 \\
(0.189)\end{array}$ \\
\hline Prob-3 & $\begin{array}{c}0.473^{* * *} \\
(0.0983)\end{array}$ & $\begin{array}{c}0.289^{* *} \\
(0.132)\end{array}$ & $\begin{array}{c}0.455^{* *} \\
(0.202)\end{array}$ \\
\hline Prob-4 & $\begin{array}{c}0.765^{* * *} \\
(0.104)\end{array}$ & $\begin{array}{c}0.589^{* * *} \\
(0.139)\end{array}$ & $\begin{array}{c}0.424^{* *} \\
(0.213)\end{array}$ \\
\hline Medium & $\begin{array}{c}-0.164^{* *} \\
(0.0725)\end{array}$ & $\begin{array}{l}-0.0517 \\
(0.0971)\end{array}$ & $\begin{array}{c}-0.266^{*} \\
(0.148)\end{array}$ \\
\hline Large & $\begin{array}{c}-0.512^{* * *} \\
(0.0753)\end{array}$ & $\begin{array}{c}-0.602^{* * *} \\
(0.104)\end{array}$ & $\begin{array}{c}0.191+ \\
(0.152)\end{array}$ \\
\hline With some diff. & $\begin{array}{c}-0.180^{* *} \\
(0.0715)\end{array}$ & $\begin{array}{c}-0.277^{* * *} \\
(0.0968)\end{array}$ & $\begin{array}{l}0.213+ \\
(0.146)\end{array}$ \\
\hline Difficult & $\begin{array}{c}-0.369^{* * *} \\
(0.0743)\end{array}$ & $\begin{array}{c}-0.464^{* * *} \\
(0.102)\end{array}$ & $\begin{array}{l}0.197+ \\
(0.151)\end{array}$ \\
\hline Couple & $\begin{array}{c}0.0131 \\
(0.0870)\end{array}$ & $\begin{array}{l}0.0136 \\
(0.118)\end{array}$ & $\begin{array}{c}-0.0241 \\
(0.177)\end{array}$ \\
\hline $2+2$ ch. & $\begin{array}{c}0.107 \\
(0.0982)\end{array}$ & $\begin{array}{l}0.0191 \\
(0.134)\end{array}$ & $\begin{array}{c}0.176 \\
(0.199)\end{array}$ \\
\hline $2+2$ ch.+eld. & $\begin{array}{c}-0.218^{* *} \\
(0.111)\end{array}$ & $\begin{array}{c}-0.195+ \\
(0.151)\end{array}$ & $\begin{array}{c}-0.0904 \\
(0.226)\end{array}$ \\
\hline 2 pieces & $\begin{array}{c}0.0516 \\
(0.0809)\end{array}$ & $\begin{array}{c}0.124 \\
(0.109)\end{array}$ & $\begin{array}{l}-0.166 \\
(0.165)\end{array}$ \\
\hline 3 pieces & $\begin{array}{c}0.106 \\
(0.0987)\end{array}$ & $\begin{array}{c}0.251^{*} \\
(0.134)\end{array}$ & $\begin{array}{c}-0.334^{*} \\
(0.201)\end{array}$ \\
\hline
\end{tabular}




\begin{tabular}{c|c|c|c}
\hline \multirow{2}{*}{ Variable } & Baseline & \multicolumn{2}{c}{ Presentation order } \\
\cline { 2 - 4 } & $\beta$ & $\beta$ & $\beta$ \\
\hline \hline \multirow{2}{*}{ 3+ pieces } & $0.141+$ & $0.242^{*}$ & -0.201 \\
& $(0.104)$ & $(0.141)$ & $(0.211)$ \\
\hline Employed & $0.517^{* * *}$ & $0.598^{* * *}$ & -0.197 \\
& $(0.0799)$ & $(0.110)$ & $(0.162)$ \\
\hline Unemployed & 0.0939 & 0.0706 & 0.0418 \\
& $(0.0827)$ & $(0.113)$ & $(0.168)$ \\
\hline \hline Observations & 3990 & 3990 & \\
\hline Standard errors in parenthesis, $* * *-p<0.01, * *-p<0.05, *-p<0.1,+-p<0.2$.
\end{tabular}

\section{Estimation Results for the Models with Alternative Error Spec- ification}

\begin{tabular}{|c|c|c|c|}
\hline Variable & Baseline & Bootstrap (200 iter.) & Robust error \\
\hline & $\beta$ & $\beta$ & $\beta$ \\
\hline 22 years & $\begin{array}{l}0.171+ \\
(0.111)\end{array}$ & $\begin{array}{l}0.171+ \\
(0.111)\end{array}$ & $\begin{array}{l}0.171+ \\
(0.111)\end{array}$ \\
\hline 27 years & $\begin{array}{l}0.177+ \\
(0.120)\end{array}$ & $\begin{array}{l}0.177+ \\
(0.113)\end{array}$ & $\begin{array}{l}0.177+ \\
(0.119)\end{array}$ \\
\hline 34 years & $\begin{array}{l}0.256^{*} \\
(0.134)\end{array}$ & $\begin{array}{l}0.256^{*} \\
(0.139)\end{array}$ & $\begin{array}{l}0.256^{*} \\
(0.135)\end{array}$ \\
\hline 44 years & $\begin{array}{c}0.0524 \\
(0.122)\end{array}$ & $\begin{array}{c}0.0524 \\
(0.120)\end{array}$ & $\begin{array}{c}0.0524 \\
(0.121)\end{array}$ \\
\hline Women & $\begin{array}{c}0.0597 \\
(0.0500)\end{array}$ & $\begin{array}{c}0.0597 \\
(0.0495)\end{array}$ & $\begin{array}{c}0.0597 \\
(0.0500)\end{array}$ \\
\hline Very Poor & $\begin{array}{c}0.108+ \\
(0.0741)\end{array}$ & $\begin{array}{c}0.108+ \\
(0.0806)\end{array}$ & $\begin{array}{c}0.108+ \\
(0.0733)\end{array}$ \\
\hline Poor & $\begin{array}{c}0.393^{* * *} \\
(0.0798)\end{array}$ & $\begin{array}{c}0.393^{* * *} \\
(0.0851)\end{array}$ & $\begin{array}{c}0.393^{* * *} \\
(0.0794)\end{array}$ \\
\hline Prob-2 & $\begin{array}{c}0.276^{* * *} \\
(0.0928)\end{array}$ & $\begin{array}{c}0.276^{* * *} \\
(0.0929)\end{array}$ & $\begin{array}{c}0.276^{* * *} \\
(0.0925)\end{array}$ \\
\hline Prob-3 & $\begin{array}{c}0.473^{* * *} \\
(0.0983) \\
\end{array}$ & $\begin{array}{c}0.473^{* * *} \\
(0.0979)\end{array}$ & $\begin{array}{c}0.473^{* * *} \\
(0.0989)\end{array}$ \\
\hline Prob-4 & $\begin{array}{c}0.765^{* * *} \\
(0.104)\end{array}$ & $\begin{array}{c}0.765^{* * *} \\
(0.106)\end{array}$ & $\begin{array}{c}0.765^{* * *} \\
(0.105)\end{array}$ \\
\hline Medium & $\begin{array}{c}-0.164^{* *} \\
(0.0725)\end{array}$ & $\begin{array}{c}-0.164^{* *} \\
(0.0762)\end{array}$ & $\begin{array}{c}-0.164^{* *} \\
(0.0723)\end{array}$ \\
\hline Large & $\begin{array}{c}-0.512^{* * *} \\
(0.0753)\end{array}$ & $\begin{array}{c}-0.512^{* * *} \\
(0.0790)\end{array}$ & $\begin{array}{c}-0.512^{* * *} \\
(0.0755)\end{array}$ \\
\hline With some diff. & $\begin{array}{c}-0.180^{* *} \\
(0.0715)\end{array}$ & $\begin{array}{c}-0.180^{* * *} \\
(0.0693)\end{array}$ & $\begin{array}{c}-0.180^{* *} \\
(0.0719)\end{array}$ \\
\hline Difficult & $\begin{array}{c}-0.369^{* * *} \\
(0.0743)\end{array}$ & $\begin{array}{c}-0.369^{* * *} \\
(0.0773)\end{array}$ & $\begin{array}{c}-0.369^{* * *} \\
(0.0741)\end{array}$ \\
\hline Couple & $\begin{array}{c}0.0131 \\
(0.0870)\end{array}$ & $\begin{array}{c}0.0131 \\
(0.0856)\end{array}$ & $\begin{array}{c}0.0131 \\
(0.0868)\end{array}$ \\
\hline
\end{tabular}




\begin{tabular}{c|c|c|c}
\hline Variable & Baseline & Bootstrap (200 iter.) & Robust error \\
\hline \hline $2+2$ ch. & $\beta$ & $\beta$ & $\beta$ \\
& 0.107 & 0.107 & 0.107 \\
& $(0.0982)$ & $(0.103)$ & $(0.0986)$ \\
\hline $2+2$ ch.+eld. & $-0.218^{* *}$ & $-0.218^{* *}$ & $-0.218^{* *}$ \\
& $(0.111)$ & $(0.105)$ & $0.111)$ \\
\hline 2 pieces & 0.0516 & 0.0516 & 0.0516 \\
& $(0.0809)$ & $(0.0830)$ & $0.0806)$ \\
\hline 3 pieces & 0.106 & 0.106 & 0.106 \\
& $(0.0987)$ & $(0.102)$ & $0.0983)$ \\
\hline $3+$ pieces & $0.141+$ & $0.141+$ & $(0.104)$ \\
& $(0.104)$ & $(0.107)$ & $0.517^{* * *}$ \\
\hline Employed & $0.517^{* * *}$ & $0.517^{* * *}$ & $0.0801)$ \\
\hline Unemployed & $(0.0799)$ & $(0.0773)$ & 0.0939 \\
& $(0.0939$ & 0.0939 & $(0.0829)$ \\
\hline \hline Observations & 3990 & $(0.0866)$ & 3990 \\
\hline Standard errors in parenthesis, $* * *-p<0.01, * *-p<0.05, *-p<0.1,+-p<0.2$.
\end{tabular}


Estimation Results for the Model Based on Linear Utility

\begin{tabular}{c|c}
\hline Variable & $\beta$ \\
\hline Age & $0.0640+$ \\
& $(0.0395)$ \\
\hline Age=44 years & 0.0477 \\
& $(0.134)$ \\
\hline Woman & $0.0850^{*}$ \\
& $(0.0490)$ \\
\hline Wealth & $0.173^{* * *}$ \\
& $(0.0381)$ \\
\hline Prob. & $0.240^{* * *}$ \\
& $(0.0279)$ \\
\hline Loan size & $-0.232^{* * *}$ \\
& $(0.0357)$ \\
\hline Monit. possib. & $-0.179^{* * *}$ \\
& $(0.0359)$ \\
\hline Family size & $-0.0533+$ \\
& $(0.0348)$ \\
\hline Living cond. & $0.0550^{*}$ \\
& $(0.0319)$ \\
\hline Prev.occup = employed & $0.502^{* * *}$ \\
& $(0.0779)$ \\
\hline Prev. occup. = Unemployed & $0.139^{*}$ \\
& $(0.0730)$ \\
\hline Standard errors in parenthesis, $* * * p<0.01, * *-p<0.05, *-p<0.1,+-p<0.2$.
\end{tabular}




\section{References}

Armendáriz, B. and Morduch, J. (2010). The economics of microfinance. The MIT Press.

Aubert, C., de Janvry, A., and Sadoulet, E. (2009). Designing credit agent incentives to prevent mission drift in pro-poor microfinance institutions. Journal of Development Economics, 90(1):153-162.

Banerjee, A., Duflo, E., Glennerster, R., and Kinnan, C. (2009). The miracle of microfinance? Evidence from a randomized evaluation. Department of Economics, Massachusetts Institute of Technology (MIT) Working Paper, May.

Besley, T. and Ghatak, M. (2005). Competition and incentives with motivated agents. The American Economic Review, 95(3):616-636.

Carlsson, F. and Martinsson, P. (2001). Do Hypothetical and Actual Marginal Willingness to Pay Differ in Choice Experiments? Application to the Valuation of the Environment. Journal of Environmental Economics and Management, 41(2):179-192.

Cull, R., Demirgüç-Kunt, A., and Morduch, J. (2007). Financial performance and outreach: a global analysis of leading microbanks. Economic Journal, 117.

Cull, R., Demirgüç-Kunt, A., and Morduch, J. (2009). Microfinance meets the market. Journal of Economic Perspectives, 23(1):167-192.

D'Espallier, B., Guérin, I., and Mersland, R. (2010). Women and repayment in microfinance: A Global Analysis. World Development, doi:10.1016/j.worlddev.2010.10.008.

Fischer, G. and Ghatak, M. (2010). Spanning the Chasm: Uniting Theory and Empirics in Microfinance research. Forthcoming in B. Armendariz and M. Labie (eds), The Handbook of Microfinance, London-Singapore: Scientific Work.

Francois, P. and Vlassopoulos, M. (2008). Pro-social Motivation and the Delivery of Social Services. CESifo Economic Studies, 54(1):22.

Galariotis, E., Villa, C., and Yusupov, N. (2011). Recent Advances in Lending to The Poor with Asymmetric Information. Journal of Development Studies, forthcoming.

Ghatak, M. and Guinnane, T. (1999). The economics of lending with joint liability: theory and practice. Journal of Development Economics, 60(1):195-228.

Hermes, N. and Lensink, R. (2007). The Empirics of Microfinance: What Do We Know? The Economic Journal, 117:F1-F10.

Ibanez, M. and Carlsson, F. (2010). A survey-based choice experiment on coca cultivation. Journal of Development Economics, 93:249-263. 
Karlan, D. and Morduch, J. (2009). Access to Finance. in D. Rodrik and M. Rosenzweig, eds., Handbook of Development Economics, Amsterdam: Elsevier, 5:4704-4784.

Kessels, R., Goos, P., and Vandebroek, M. (2006). A comparison of criteria to design efficient choice experiments. Journal of Marketing Research, 43(3):409-419.

Labie, M., Méon, P.-G., Mersland, R., and Szafarz, A. (2010). Discrimination by Microcredit Officers: Theory and Evidence on Disability in Uganda . CEB Working Paper No.10/00\%.

Levitt, S. and List, J. (2009). Field experiments in economics: The past, the present, and the future. European Economic Review, 53(1):1-18.

List, J., Sinha, P., and Taylor, M. (2006). Using choice experiments to value non-market goods and services: evidence from field experiments. The BE Journal of Economic Analysis \& Policy, 6(2):2.

McFadden, D. (1974). Frontiers in Econometrics, chapter Conditional logit analysis of qualitative choice behavior, pages 105-142. Academic Press:NewYork.

McKim, A. and Hughart, M. (2005). Staff Incentive Schemes in Practice: Findings from a Global Survey of Microfinance Institutions. Microfinance Network \& CGAP, Washington $D C$.

Mersland, R. and Strøm, R. (2010). Microfinance mission drift? World Development, $38(1): 28-36$

Morduch, J. (1999). The microfinance promise. Journal of Economic Literature, 37(4):1569-1614.

Petersen, M. (2004). Information: hard and soft. Unpublished manuscript, Nortwestern University.

The World Bank (2010). World Development Indicators 2010. The World Bank.

Zwerina, K., Huber, J., and Kuhfeld, W. (1996). A general method for constructing efficient choice designs. Working Paper, Fuqua School of Business, Duke University. 